\title{
Diversity Within Streptomyces ipomoeae Based on Inhibitory Interactions, rep-PCR, and Plasmid Profiles
}

\author{
C. A. Clark, C. Chen, N. Ward-Rainey, and G. S. Pettis
}

First and second authors: Department of Plant Pathology and Crop Physiology, Louisiana State University Agricultural Center, Louisiana Agricultural Experiment Station, Baton Rouge 70803-1720; and third and fourth authors: Department of Biological Sciences, Louisiana State University, Baton Rouge 70803. Accepted for publication 27 July 1998.

\begin{abstract}
Clark, C. A., Chen, C., Ward-Rainey, N., and Pettis, G. S. 1998. Diversity within Streptomyces ipomoeae based on inhibitory interactions, rep-PCR, and plasmid profiles. Phytopathology 88:1179-1186.

Streptomyces soil rot is a destructive disease of sweetpotato (Ipomoea batatas) that causes yield loss resulting from decay of the feeder root system and reduced quality due to the presence of necrotic lesions on the storage roots. It is managed by the use of resistant cultivars, but variability of the pathogen has not been previously assessed. This study compared 36 strains of the pathogen Streptomyces ipomoeae from different locations in the United States and Japan. The strains could be separated into three groups on the basis of their ability to inhibit the growth of one

another in in vitro assays. Although some strains contained plasmids of approximately 18,42 , or $270 \mathrm{~kb}$ in size, plasmid profiles did not correspond to inhibition grouping. Fingerprinting by repetitive element-based polymerase chain reaction (rep-PCR) using outwardly facing primers for the BOX, enterobacterial repetitive intergenic consensus (ERIC), and repetitive extragenic palindromic (REP) sequences indicated relatively high genomic homogeneity within S. ipomoeae. However, cluster analysis of similarity coefficients among strains using rep-PCR data revealed clusters that correlated with the inhibition grouping. The neotype strain of $S$. ipomoeae had lower similarity values by rep-PCR than any of the other strains and could not be grouped by inhibitory interactions.
\end{abstract}

Streptomyces soil rot or pox is a destructive disease of sweetpotato, Ipomoea batatas (L.) Lam., that is caused by the soilborne actinomycete Streptomyces ipomoeae. The disease causes reduction in crop yield resulting from fibrous root rot as well as reduction in quality resulting from distortions and necrotic lesions on storage roots, which make them unmarketable $(5,37)$. For many years, the disease was known to occur only in the United States, but in the 1980 s, it was described in Japan, where it may have been present since the 1940s (5). It is possible that it occurs unreported in other countries. In recent years, in both the United States and Japan, management of this disease has relied extensively on the use of resistant cultivars. Although the resistance of commonly grown cultivars has appeared stable, some soil rot-resistant cultivars of sweetpotato were reported to vary in reaction to the disease from year to year or from location to location $(6,31)$. Whether this variability was caused by strain variation in $S$. ipomoeae or by environmental conditions is not known. Because of the reliance on resistance, there is interest in understanding genetic variation in this pathogen.

Relatively few plant diseases are caused by actinomycetes (25, 27). Scab, common scab, russet scab, and deep-pitted scab are important diseases of potato (Solanum tuberosum L.) and other root and tuber crops $(9,25,27)$. Originally, these were ascribed to a single species. However, the actinomycetes associated with these diseases are phenotypically and genotypically diverse, and several species of Streptomyces including S. scabies (23), S. acidiscabies (24), S. caviscabies (12), S. griseus, and others have been reported to cause potato scab $(7,9-11,47)$. Even among strains phenotypically consistent with the accepted description of $S$. scabies, there is greater genotypic diversity than for a conventional species, and DNA homology does not distinguish pathogenic from nonpathogenic strains (13,

Corresponding author: C. A. Clark; E-mail address: cclark@agctr.lsu.edu

Publication no. P-1998-0831-02R

(C) 1998 The American Phytopathological Society
35). Variability among scab-causing streptomycetes has been demonstrated by various phenotypic and genotypic assessments including morphological and physiological tests $(9,47)$, cellular fatty acid profiles $(2,35)$, DNA homologies $(13,35,47), 16 \mathrm{~S}$ ribosomal (r) DNA sequence analysis (46), characterization of inhibitory interactions among strains (33), protein profiles (35), restriction fragment length polymorphisms (7), and polymerase chain reaction (PCR) fingerprinting using repetitive extragenic sequences $(40,44)$.

$S$. ipomoeae has not been studied as extensively as $S$. scabies. Studies with $S$. ipomoeae, especially earlier taxonomic studies (17, $20,42,49)$, have been limited because naturally occurring nonpathogenic strains have not been isolated and few strains of this species were available. In the taxonomic studies, S. ipomoeae was represented only by the neotype strain from Louisiana. As expected, this strain did not cluster with other species, as S. ipomoeae appears to be the only species that produces blue aerial mycelia and does not produce melanin on tyrosine-containing media (21). DNA homology studies by Labeda and Lyons (22) indicated that $S$. ipomoeae was a relatively homogeneous species and was distinct from $S$. scabies. Beyazova and Lechevalier (1) used restriction endonuclease fingerprinting and plasmid profiles to assess relationships among streptomycetes; they separated 10 strains of $S$. ipomoeae into two separate clusters that were distinct from the six clusters formed by strains of $S$. albus, $S$. fradiae, $S$. lavendulae, $S$. rimosus, and $S$. somaliensis as well as from unclustered strains of the $S$. cyaneus group.

Families of repetitive DNA sequences are dispersed throughout the genomes of diverse bacterial species $(30,48)$ including streptomycetes (38). Three families of unrelated repetitive DNA sequences, BOX (154 bp), enterobacterial repetitive intergenic consensus (ERIC, $124 \mathrm{bp}$ ), and repetitive extragenic palindromic (REP, 35 to $40 \mathrm{bp}$ ), have been employed as the bases for PCR. The repetitive element-based (rep)-PCR fingerprinting technique uses outwardly facing primers complementary to these interspersed BOX, ERIC, and REP sequences to amplify different-sized DNA fragments lying between these elements (48). rep-PCR fingerprint- 
ing of different strains of Pseudomonas and Xanthomonas showed that the method could unambiguously detect genomic differences among strains and pathovars that were indistinguishable by other methods used in classification (28). rep-PCR also was used to demonstrate genomic diversity among strains of the sugarcane leaf scald pathogen, $X$. albilineans, from different serovars and geographic origins (26). Pathogenic and nonpathogenic strains of $S$. scabies and other streptomycetes used for biocontrol of potato scab have been distinguished using rep-PCR $(40,44)$.

This study was undertaken to further characterize the genetic and phenotypic diversity within a collection of strains of S. ipomoeae from several different locations within the United States and Japan and to develop a foundation for future genetic studies of this species.

\section{MATERIALS AND METHODS}

Cultivation and maintenance of strains. Most of the strains used in this study were isolated from surface-disinfested lesions from sweetpotato fibrous or storage roots. The standard isolation medium was $0.2 \mathrm{~g}$ of $\mathrm{K}_{2} \mathrm{HPO}_{4}, 0.2 \mathrm{~g}$ of $\mathrm{MgSO}_{4} \cdot 7 \mathrm{H}_{2} \mathrm{O}, 5.0 \mathrm{~g}$ of
$\mathrm{NaCl}, 2.0 \mathrm{~g}$ of $\mathrm{CaCO}_{3}, 110 \mu \mathrm{g}$ of $\mathrm{CoCl}, 1 \mathrm{~g}$ of sodium propionate, $0.05 \mathrm{~g}$ of yeast extract, $18.0 \mathrm{~g}$ of agar, and 1 liter of distilled water. The medium was amended after autoclaving and cooling to $52^{\circ} \mathrm{C}$ with a filter-sterilized mixture of $0.1 \%$ (wt/vol) raffinose, $100 \mathrm{mg}$ of cycloheximide, $150 \mathrm{mg}$ of nalidixic acid, and $25 \mathrm{mg}$ of sodium azide. Other strains were provided as lyophilized suspensions from the Agricultural Research Service Actinomycetales Culture Collection (ARSACC) by D. Labeda (U.S. Department of Agriculture, NCAUR, Peoria, IL) or provided by J. Moyer or J. Ristaino (Department of Plant Pathology, North Carolina State University, Raleigh) and are listed in Table 1. Most of the strains are in the ARSACC. Two pathogenic strains of $S$. scabies from potato (Ss-1 = 84-01-78 and Ss-2 $=84-01-70$ ) were provided by D. Lambert (University of Maine, Orono). A strain of $X$. albilineans (Xa-44) was isolated from sugarcane in Louisiana. Xa-44 was used in a previous repPCR study (26) and was used as an outgroup in this study. Cultures were preserved on silica gel crystals (36) as soon as they were received. All $S$. ipomoeae strains were isolated originally from infected sweetpotato or, in one case, from soil around sweetpotato and were identified as $S$. ipomoeae using the morphological and

TABLE 1. Sources of strains of Streptomyces ipomoeae and data on pathogenicity, plasmid profiles, and low-frequency restriction fragment analysis (LFRFA)

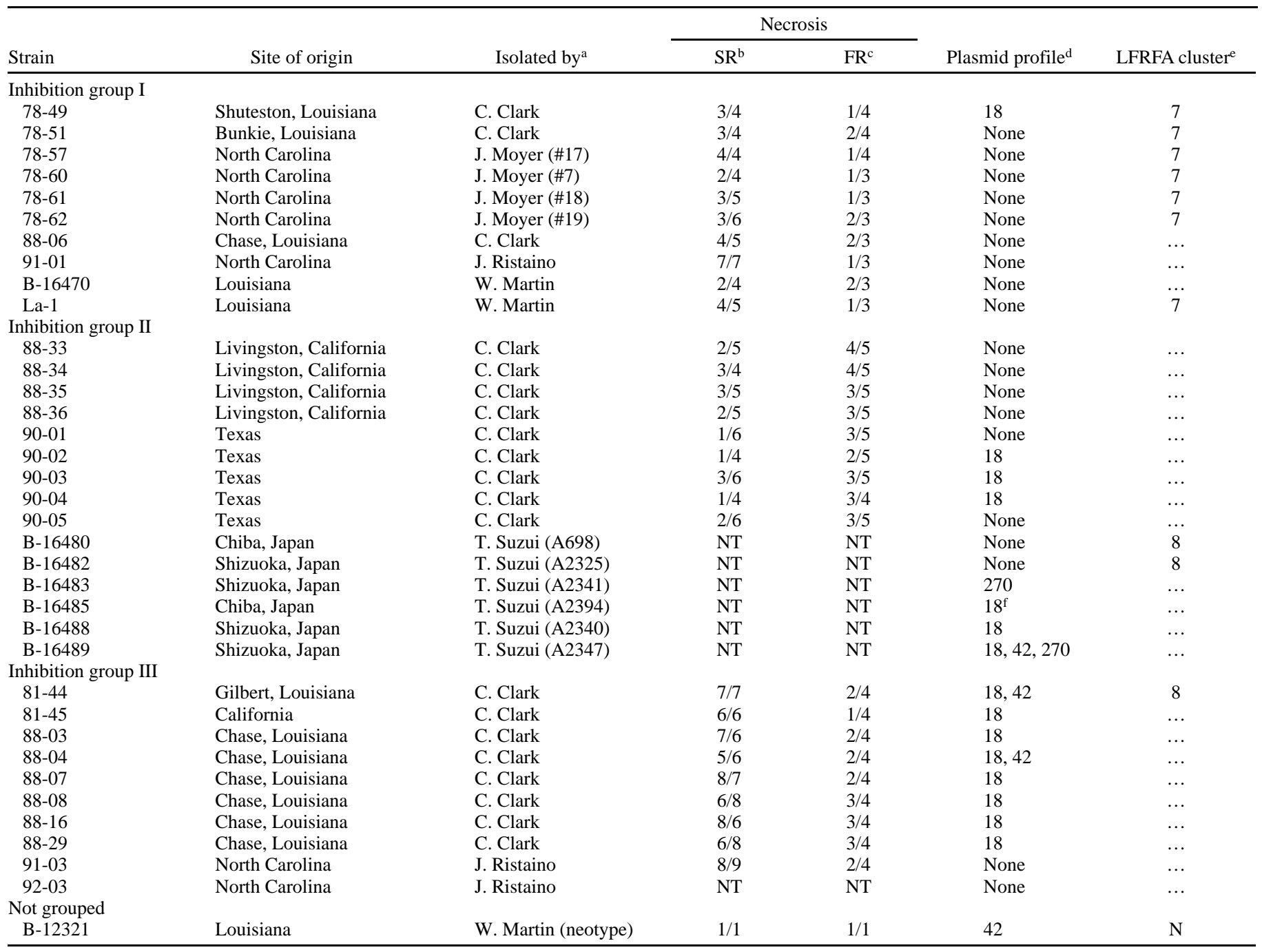

a Numbers in parentheses refer to the number given the strain by the original isolator. Cultures with a B prefix were provided by D. Labeda, USDA-ARS, NCAUR, Peoria, IL. J. Moyer and J. Ristaino are from the Department of Plant Pathology, North Carolina State University, Raleigh; T. Suzui is from the National Center for Agroecological Research, Tsukuba, Japan; and W. Martin (deceased) was from the Department of Plant Pathology and Crop Physiology, Louisiana State University, Baton Rouge.

${ }^{\mathrm{b}}$ Storage root (SR) necrosis ratings for cultivars Beauregard/Jewel using a 0 to 10 scale in which $0=$ no necrosis and $10=100 \%$ necrosis. NT $=$ not tested.

${ }^{\mathrm{c}}$ Fibrous root (FR) necrosis ratings for cultivars Beauregard/Jewel using a 0 to 5 scale in which $0=$ no necrosis and $5=100 \%$ necrosis. NT $=$ not tested.

${ }^{\mathrm{d}}$ Size of plasmids detected in kilobase $(\mathrm{kb})$.

${ }^{\mathrm{e}}$ Cluster group determined on the basis of AseI restriction fragment patterns from Beyazova and Lechevalier (1). ... not included and $\mathrm{N}=$ not clustered.

${ }^{\mathrm{f}}$ A faster migrating band, partially visible in Figure 2, was sometimes present. By hybridization assay, it was related to the 18-kb plasmid (data not shown). 
physiological characteristics from the International Streptomyces Project (41). All strains produced spore chains of the retinaculumapertum type, although some also produced spiral spore chains or spore chains that were aggregated into balls (4). All strains produced blue aerial mycelia, did not produce melanin, and utilized as a sole carbon source D-glucose, L-arabinose, sucrose, D-xylose, mannitol, $\beta$-D-fructose, $\alpha$-L-rhamnose, and D-raffinose. Galacturonic acid was not utilized as a sole carbon source by any of the strains tested.

Three media were used for culturing. S. ipomoeae growth agar (SIGA) contained $1 \mathrm{~g}$ of sodium propionate, $20 \mathrm{~g}$ of mannitol, $0.2 \mathrm{~g}$ of $\mathrm{K}_{2} \mathrm{HPO}_{4}, 0.2 \mathrm{~g}$ of $\mathrm{MgSO}_{4} \cdot 7 \mathrm{H}_{2} \mathrm{O}, 5 \mathrm{~g}$ of $\mathrm{NaCl}, 2 \mathrm{~g}$ of $\mathrm{CaCO}_{3}$, $110 \mu \mathrm{g}$ of $\mathrm{CoCl}, 1 \mathrm{~g}$ of yeast extract, and $18 \mathrm{~g}$ of agar per liter (4). Inoculum for pathogenicity tests was produced on vermiculite growth medium (VGM). This was made by adding three volumes of SIGA, modified by omitting agar and reducing the mannitol content to $5 \mathrm{~g} / \mathrm{liter}$, to four volumes of fine vermiculite and autoclaving for $1 \mathrm{~h}$ on each of 2 successive days. Tryptic soy broth (TSB; Difco Laboratories, Detroit) was used for growing mycelia for DNA extractions. Dense, visibly turbid suspensions of spores were prepared in sterile distilled water for each strain from 7- to 14-day-old SIGA cultures.

Pathogenicity tests. Pathogenicity was determined by modifications of the methods developed by Moyer et al. (34) for screening sweetpotato germ plasm for resistance. A spore suspension was added to each flask of VGM and thoroughly mixed with the medium, which was then incubated at $32^{\circ} \mathrm{C}$ for 2 to 4 weeks. The resulting inoculum was either used directly to assess pathogenicity on sweetpotato storage root slices or mixed with soil to assess pathogenicity to fibrous roots in a greenhouse. Storage root pathogenicity was determined by pressing 5- to 7-mm-thick slices cut from surface-disinfested storage roots on the surface of a layer of inoculum and incubating at $32^{\circ} \mathrm{C}$ for 1 week. Callus tissue that developed during the incubation was gently scraped off the cut surface with a knife. Necrosis was rated using the 0 to 10 scale of Moyer et al. (34) for estimating percent surface area that was necrotic. For fibrous root necrosis evaluations, 1 volume of inoculum was mixed with 100 volumes of an autoclaved 1:1 (vol/vol) mixture of river silt and sand, which was then added to 10-cm-diameter clay pots. A single vine cutting was planted in each pot, and the pots were watered well for 1 week to initiate root development. Thereafter, pots were watered only when the plants wilted in order to maintain dry soil conditions that favor Streptomyces soil rot development. After about 6 weeks, the soil was gently washed from the roots and necrosis of fibrous roots was rated on a 0 to 5 scale (34). For both assays, two cultivars were used: Jewel, which is susceptible, and Beauregard, which is rated as intermediate to resistant to Streptomyces soil rot. At least two tests with similar results were done with each strain.

Inhibition phenotype determination. Inhibition phenotypes were determined by a modification of the method of McQueen et al. (33). A 100- $\mu$ l aliquot of a dense suspension of the test strain was spread over the surface of dried (20 min in a laminar flow hood) SIGA in a 9-cm-diameter petri dish. The plate was redried for an additional $20 \mathrm{~min}$, and the challenge strain was applied by placing a 10- $\mu$ d drop of spore suspension on the surface of the SIGA and redrying for $10 \mathrm{~min}$. The cultures were incubated at $32^{\circ} \mathrm{C}$ and examined daily. All pairings were tested at least twice with similar results.

Pulsed-field gel electrophoresis. Plasmids were detected by pulsed-field gel electrophoresis of total DNA preparations in agarose inserts. Agarose inserts for pulsed-field gel electrophoresis were prepared as described by Kieser et al. (18), modified by the use of TSB for growth of the S. ipomoeae strains and omission of phenyl methylsulfonyl fluoride treatment.

Agarose inserts were loaded onto a $1 \%$ (wt/vol) agarose gel prepared in $0.5 \times$ Tris-borate EDTA $(\mathrm{TBE} ; 1 \times \mathrm{TBE}=0.089 \mathrm{M}$ Tris, $0.089 \mathrm{M}$ boric acid, and 0.002 M EDTA, pH 8.3). Electrophoresis was performed using a Bio-Rad (Bio-Rad Laboratories, Hercules,
CA) CHEF DR II apparatus with the following run parameters: field strength $=200 \mathrm{~V}$, initial switch time $=1 \mathrm{~s}$, final switch time $=$ $20 \mathrm{~s}$, and run time $=20 \mathrm{~h}$. A low-range pulsed-field gel marker (New England Biolabs, Inc., Beverley, MA) was used as a standard. Gels were stained with ethidium bromide and documented using the Stratagene Eagle Eye II (Stratagene Inc., La Jolla, CA) still video system. Two to four independent plasmid assays were conducted for each strain.

Repetitive sequence PCR. Genomic DNA was extracted from all strains except $88-35$ by a modified method of Simonet et al. (43). After centrifugation and washing two to three times with TE8 (50 mM Tris and $20 \mathrm{mM}$ EDTA, pH 8), $0.1 \mathrm{~g}$ of TSB-cultured cells were incubated with $1 \mathrm{ml}$ of TES (50 mM Tris, $20 \mathrm{mM}$ EDTA, and $10 \%$ [wt/vol] sucrose, $\mathrm{pH} 8$ ) containing $5 \mathrm{mg}$ of lysozyme per $\mathrm{ml}$ and $0.5 \mathrm{mg}$ of achromopeptidase per $\mathrm{ml}$ for $60 \mathrm{~min}$ at $37^{\circ} \mathrm{C}$. Fifty microliters of $10 \%$ sodium dodecyl sulfate (SDS) was then added and the mixture incubated at $70^{\circ} \mathrm{C}$ for $15 \mathrm{~min}$. The mixture was amended with $200 \mu \mathrm{l}$ of $1 \mathrm{~N} \mathrm{NaOH}$, incubated $15 \mathrm{~min}$ at room temperature, and $500 \mu \mathrm{l}$ of $2 \mathrm{M}$ Tris- $\mathrm{HCl}(\mathrm{pH} 7)$ was added. Proteins were removed by phenol-chloroform extraction. The genomic DNA was precipitated by $95 \%$ ethanol, washed with $70 \%$ ethanol, and dissolved in TE (10 mM Tris and $1 \mathrm{mM}$ EDTA, pH 8). DNA concentrations were determined using a TKO 100 mini-fluorometer according to the manufacturer's instructions (Hoefer Scientific Instruments, San Francisco), and 5 to 10 ng of genomic DNA was used in each PCR reaction.

BOXA1R, REP (REP1R-I and REP2-I), and ERIC (ERIC1R and ERIC2) primers (48) were synthesized by Gene Lab (School of Veterinary Medicine, Louisiana State University, Baton Rouge). Sequences of these primers $(29,48)$ are BOXA1R $=5^{\prime}$-CTACGGCAAGGCGACGCTGACG-3', REP1R-I = 5'-IIIICGICGICATCIGGC-3', REP2-I = 5'-ICGICTTATCIGGCCTAC-3', ERIC1R = 5'-ATGTAAGCTCCTGGGGATTCAC-3', and ERIC2 = 5'-AAGTAAGTGACTGGGGTGAGCG-3' $(\mathrm{I}=$ inosine). PCR reactions were carried out in $25-\mu \mathrm{l}$ aliquots containing $10 \%$ dimethyl sulfoxide, $2 \mathrm{U}$ of Taq polymerase (Promega Corp., Madison, WI), $2.5 \mu \mathrm{l}$ of 10× Promega buffer (Promega Corp.), $6 \mathrm{mM} \mathrm{MgCl} 2,1.25 \mathrm{mM}$ dNTP, $1 \mu \mathrm{l}$ of primers $(25 \mu \mathrm{M}), 5$ to $10 \mathrm{ng}$ of genomic DNA, and autoclaved Mili-Q water (Millipore Corp., Bedford, MA). Each tube was overlaid with two drops of mineral oil and centrifuged at $8,160 \times$ $g$ for $1 \mathrm{~min}$. PCR amplification was performed with a Perkin-Elmer thermal cycler (Perkin-Elmer Corp., Norwalk, CT) programmed for the following cycles: one initial denaturation step at $95^{\circ} \mathrm{C}$ for $5 \mathrm{~min}$ followed by 30 cycles of denaturation at $94^{\circ} \mathrm{C}$ for $1 \mathrm{~min}$, annealing at $50^{\circ} \mathrm{C}$ (except for REP primers, for which $40^{\circ} \mathrm{C}$ was used) for $1 \mathrm{~min}$, and extension at $65^{\circ} \mathrm{C}$ for $4 \mathrm{~min}$. After PCR, $5 \mu \mathrm{l}$ of $6 \times$ loading buffer was added to each tube, mixed well, and $8 \mu 1$ of the mixture was loaded into a $1.5 \%$ agarose gel and electrophoresed in $0.75 \times$ Tris-acetate-EDTA buffer at room temperature for $2 \mathrm{~h}$ at $5 \mathrm{~V} / \mathrm{cm}$. The gel was stained with $0.5 \mu \mathrm{g}$ of ethidium bromide for 10 to 15 min, destained with distilled water, and photographed. Two independent amplifications with similar results were conducted for each strain-primer combination.

The comparisons of DNA fingerprint patterns were performed by measurement of band positions of PCR products following electrophoretic separation (48). The presence or absence of an intense reproducible band at each location within the gel was scored $(1=$ presence, $0=$ absence) and used to produce a two-dimensional rectangular data matrix of binary values for all strains of interest. Computer-assisted cluster analyses were performed with the biostatistical analysis program NTSYS-pc (Applied Biostatistics, Inc., Setauket, NY). The similarity for qualitative data (SIMQUAL) computational subroutine was used with the DICE coefficient. Similarity groups were derived from the similarity indices via the unweighted pair group mathematical averaging method and presented as dendrograms of relatedness within the sequential, agglomerative, hierarchical, and nested or nonoverlapping methods (SAHN) program (48). Strain Xa-44 of $X$. albilineans was chosen as an un- 
related outgroup because rep-PCR profiles could be compared with a previous study (26).

\section{RESULTS}

Pathogenicity. With the exception of the neotype strain B-12321 (= ISP-5383 = ATCC-25462), all of the strains caused necrosis on both fibrous and storage roots of 'Jewel' and, to a lesser extent, 'Beauregard' (Table 1). Because it is difficult to accurately control the concentration of inoculum used, relative degrees of virulence or aggressiveness cannot be readily compared among the strains using this data. However, all the strains appeared to cause greater fibrous root necrosis on the susceptible cultivar Jewel than on the resistant cultivar Beauregard.

Inhibition phenotypes. Four different types of interactions between $S$. ipomoeae strains were observed in culture when strains were spotted on lawns of different test strains. In many cases, there was no apparent effect of the cocultured strains on each other and their growth appeared similar to growth when a strain was tested against itself. In other cases, a broad (about 2 to $4 \mathrm{~mm}$ ) zone of inhibition appeared in the lawn after 2 days and persisted indefinitely (Fig. 1). There were no mycelia within this zone. In some of these pairings, there was no apparent effect on the test strain outside the zone of growth inhibition, while in others, development of aerial mycelia was inhibited in a second zone surrounding the zone of inhibition (Fig. 1). The fourth type of interaction was similar in appearance to 'pock' or 'lethal zygosis' reactions, which are characteristically associated with the transfer of conjugative plasmids in streptomycetes $(8,14,33)$; no effect was evident on growth after 2 days, but a narrow $(\leq 1 \mathrm{~mm})$ clear zone appeared in the test lawn by 4 days (Fig. 1). Disregarding pock reactions, three large groups of strains were defined based on development of the broad zone of inhibition at 2 days (Table 1). Group I included strains that did not induce inhibition in lawns of any other strains by 2 days and were inhibited when grown as test lawns by all strains in groups II and III. Group II strains inhibited all group I and III strains and were inhibited by group III strains. Group III strains inhibited group I and II strains and were inhibited by group II strains. Pock formation was evident only in pairings of certain strains from within the same group (data not shown). Pairings between members of different groups could not be assessed for the pock reaction, because the broad inhibition zones would have obscured the pock reactions that develop later. Pock reactions were induced by strains $78-49,88-33,88-34,88-35,90-05$, B16483, B16488, B16489, 81-45, 88-03, 88-04, 88-08, 88-16, 88-29, 91-03, and 92-03. None of these induced pock reactions in all members of the same inhibition group, and most induced pocking in only a small proportion of the strains. Strain B-12321 varied from test to test and did not clearly fall into any of the three inhibition groups. B12321 challenge induced inhibition zones in lawns of some, but not all, members of both inhibition groups I and II, but in some cases, it was difficult to distinguish whether the zone that developed was a weak inhibition or a pock reaction.

Plasmid profiles. Three plasmid bands with estimated molecular masses of 12 to 20,42 , and $270 \mathrm{~kb}$ were observed by pulsedfield agarose gel electrophoresis (Fig. 2) or when plasmids were extracted by an alkaline lysis method (14) and analyzed by standard agarose gel electrophoresis (data not shown). Estimates of the size of the smallest plasmid varied between runs in which dif-

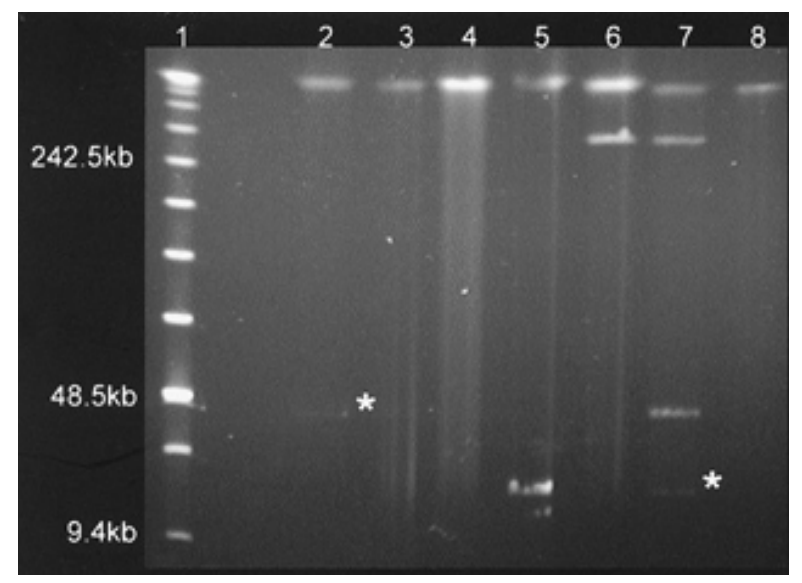

Fig. 2. Agarose pulsed-field electrophoresis gel of plasmid DNA. Lane 1, size standard; lane 2, strain B12321; lane 3, 88-06; lane 4, 90-05; lane 5, B16485; lane 6, B16483; lane 7, B16489; and lane 8, 92-03. Asterisk indicates presence of faint plasmid band.

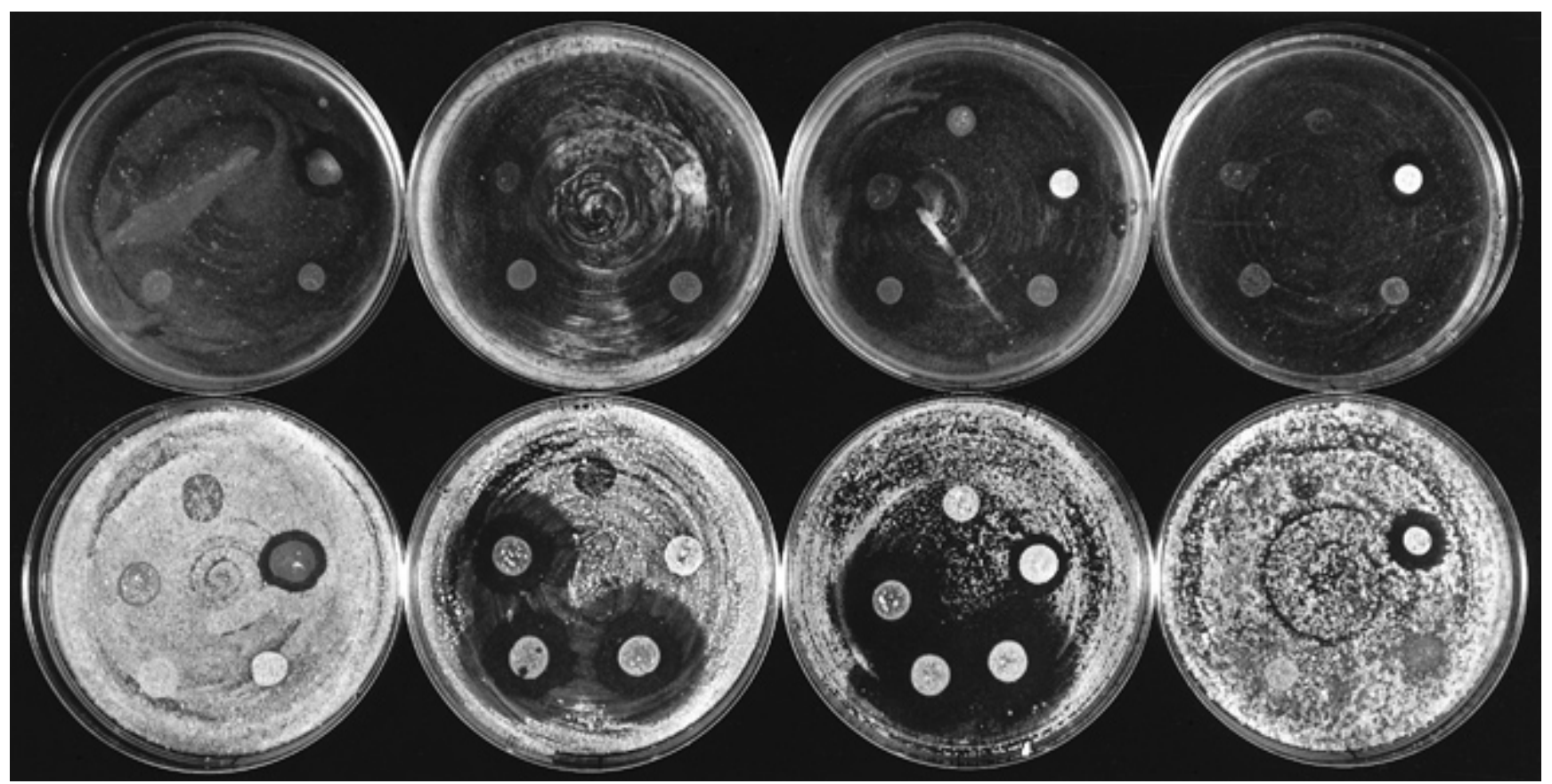

Fig. 1. Inhibition assays among Streptomyces ipomoeae strains. Top row = plates incubated for 2 days and bottom row = plates incubated for 4 days. The lawns are of 81-45 (far left column), 90-1 (middle left), 78-49 (middle right), and 88-03 (far right). Each lawn was over-spotted with a 10- $\mu$ aliquot of a spore suspension of 78-49, 90-01, 88-29, 81-45, and 88-03 (proceeding clockwise from top). 
ferent standards and run parameters were used and is hereafter designated as the $18-\mathrm{kb}$ plasmid. Of the 36 strains investigated, 18 contained plasmids (Table 1). The greatest diversity in plasmid profile was seen within inhibition group II, and the $270-\mathrm{kb}$ plasmids were only observed in members of this group (Fig. 2). One member of group II, strain B-16485, appeared to have a much higher copy number of an 18-kb plasmid than the other strains, as judged by the intensity of the plasmid band (Fig. 2). This effect was reproducible over several electrophoresis runs and was found in agarose inserts prepared by both the methods of Kieser et al. (18) and Beyazova and Lechevalier (1) (data not shown). Strain 78-49 may have had low copy numbers of the same plasmid, because it produced only faint bands in some runs and no visible band in other runs.

Repetitive sequence PCR. Results from BOXA1R-primed PCR are shown in Figure 3. All of the 35 strains of S. ipomoeae shared five intense bands and one less-intense band. The length of amplified DNA ranged from less than $0.5 \mathrm{~kb}$ to approximately $3.7 \mathrm{~kb}$; however, most intense bands ranged from 0.5 to $1.6 \mathrm{~kb}$. Strains differed in the presence or absence of a few bands. The type strain B12321 lacked two bands possessed by all other S. ipomoeae strains: one of approximately $1.64 \mathrm{~kb}$ and another of approximately $1.02 \mathrm{~kb}$. However, B12321 produced another weak band only slightly smaller than the $1.02-\mathrm{kb}$ intense band possessed by all other S. ipomoeae strains. The banding patterns of two strains of $S$. scabies and one strain of $X$. albilineans were clearly different from those of $S$. ipomoeae.

The REP PCR-amplified DNA bands ranged from approximately 0.5 to $4.1 \mathrm{~kb}$ (Fig. 3). The $S$. ipomoeae strains appeared to have more diverse patterns than with the ERIC or BOX primers. Six bands were shared by all $S$. ipomoeae strains, and the type strain

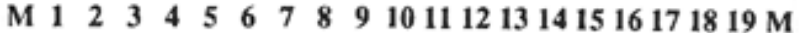

\section{20212223242526272829303132333435363738 M}
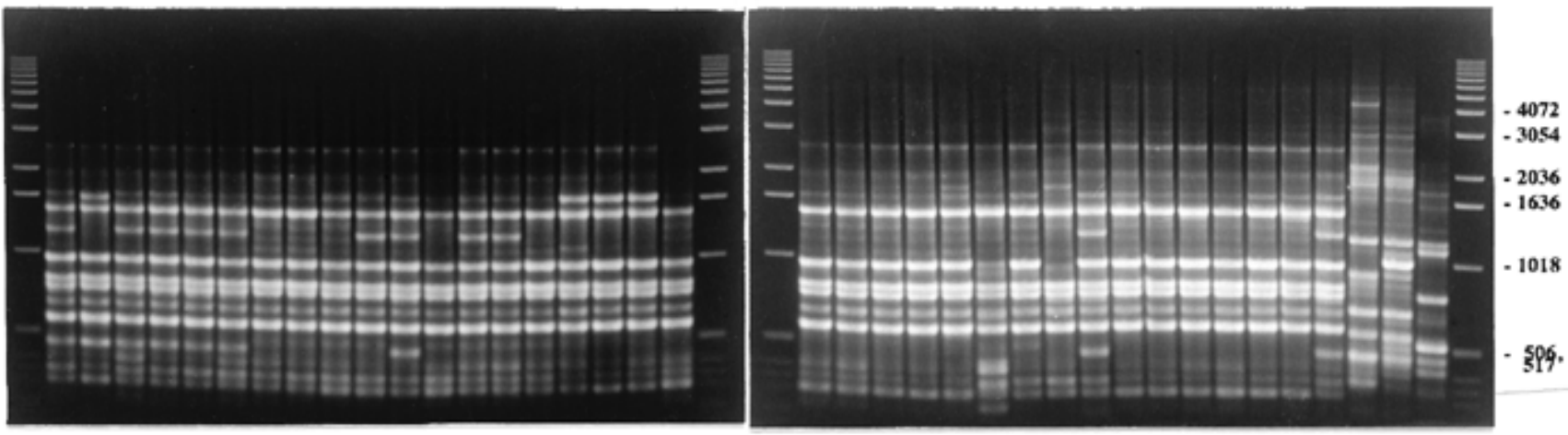

$\begin{array}{lllllllllllllll}M & 1 & 2 & 3 & 4 & 5 & 6 & 7 & 8 & 9 & 1011 & 121314151617 & 1819 & M\end{array}$
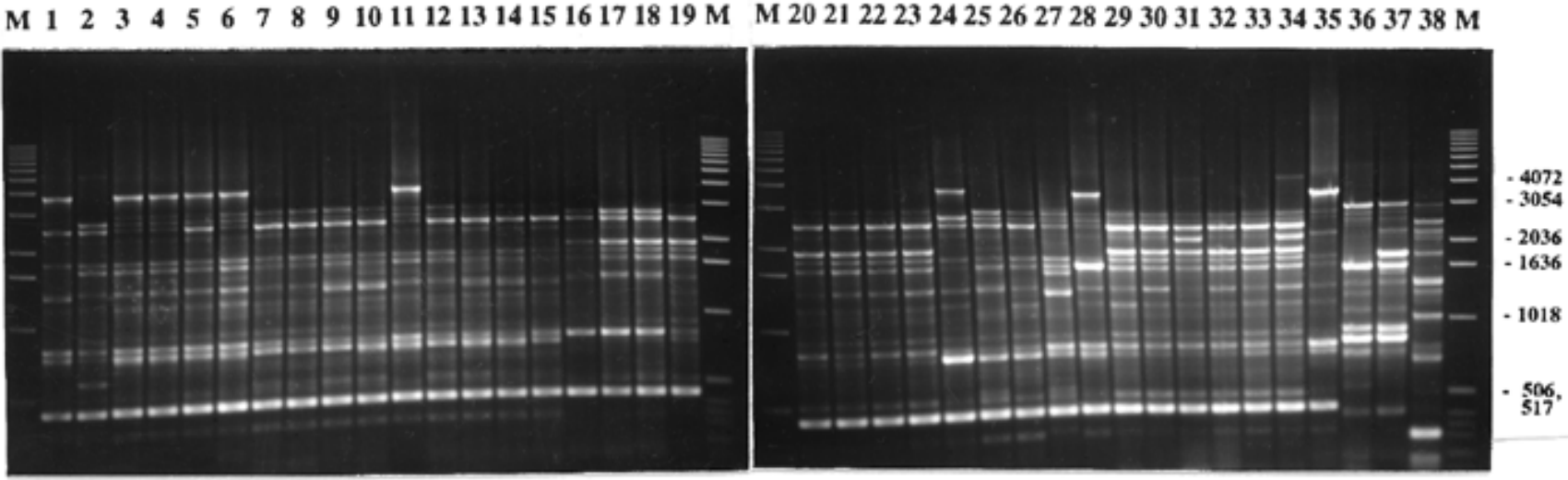

M $12234556788910111213141516171819 M$
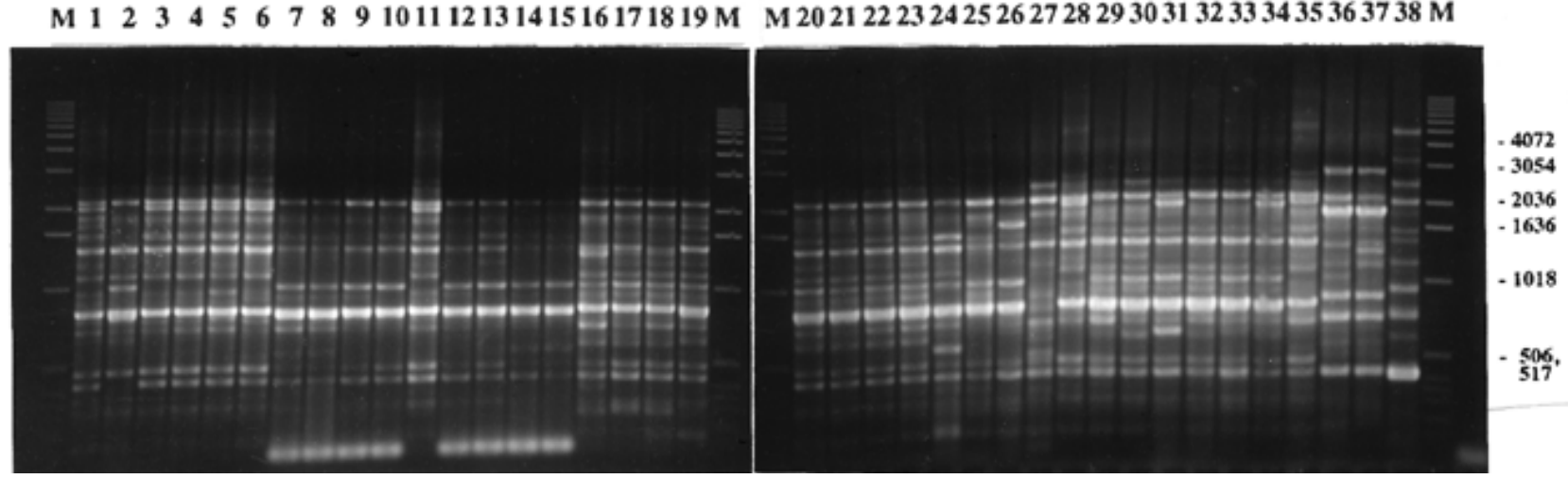

Fig. 3. Agarose electrophoresis gels of repetitive element-based polymerase chain reaction products generated from genomic DNA of isolates of Streptomyces spp. Top $=$ BOXA1R primer, middle $=$ repetitive extragenic palindromic $(\mathrm{REP}) 1 \mathrm{R}$ and REP2-I primers, and bottom $=$ enterobacterial repetitive intergenic consensus (ERIC)1R and ERIC2 primers. Lanes labeled $\mathrm{M}$ were run with the DNA size standard (1-kb ladder; Gibco-BRL, Gaithersburg, MD), sizes of fragments (bp) are indicated on the right. Lane 1, strain 78-49; lane 2, 78-51; lane 3, 78-57; lane 4, 78-60; lane 5, 78-61; lane 6, 78-62; lane 7, 81-44; lane 8, 81-45; lane 9, 88-03; lane 10, 88-04; lane 11, 88-06; lane 12, 88-07; lane 13, 88-08; lane 14, 88-16; lane 15, 88-29; lane 16, 88-33; lane 17, 88-34; lane 18, 88-36; lane 19, 90-01; lane 20,90-02; lane 21, 90-03; lane 22, 90-04; lane 23, 90-05; lane 24, 91-01; lane 25,=91-03; lane 26, 92-03; lane 27, B12321; lane 28,= B16740; lane 29, B16480; lane 30, B16482; lane 31, B16483; lane 32, B16485; lane 33, B16488; lane 34, B16489; lane 35, La-1; lane 36, Ss-1; lane 37, Ss-2; and lane 38, Xa-44. 
B12321 lacked at least one band shared by all other S. ipomoeae strains. Differences between $S$. ipomoeae strains and S. scabies strains were not as evident as in those of BOX PCR.

ERIC PCR generated fewer bands than BOX and REP PCR for $S$. ipomoeae strains, and the bands ranged from less than $0.5 \mathrm{~kb}$ to approximately $2.7 \mathrm{~kb}$ (Fig. 3). All S. ipomoeae strains shared four bands, while the type strain B12321 lacked at least one band shared by all other strains. At the position corresponding to approximately $0.9 \mathrm{~kb}$, all $S$. ipomoeae strains generated an intense band except B12321, which generated a weak band at the same position.

The BOX, ERIC, and REP PCR each were scored separately for the presence or absence of bands; the data from all three sets of PCR were then combined and treated as a single set of data for NTSYS-PC analysis. BOX PCR and REP PCR each generated 36 bands of different electrophoretic mobility among the $35 \mathrm{~S}$. ipomoeae strains, $2 \mathrm{~S}$. scabies strains, and $1 \mathrm{X}$. albilineans strain, while the ERIC PCR generated 32 bands. After the SIMQUAL analysis, SAHN was run and similarities between different strains were obtained. The dendrograms for BOX, ERIC, and REP PCR were constructed separately using the data from the SAHN results (data not shown). The combined data from BOX, ERIC, and REP PCR were used to produce the dendrogram in Figure 4.

BOX PCR profiles clustered 33 of the 35 S. ipomoeae strains into one cluster at $92 \%$ similarity. Strain $78-51$ had about $85 \%$ and B12321 about $78 \%$ similarity with this cluster. However, the two S. scabies strains, Ss-1 and Ss-2, shared $80 \%$ similarity with each other, but only $21 \%$ similarity with $S$. ipomoeae strains. The strain of $X$. albilineans, Xa-44, showed only $2.7 \%$ similarity with strains

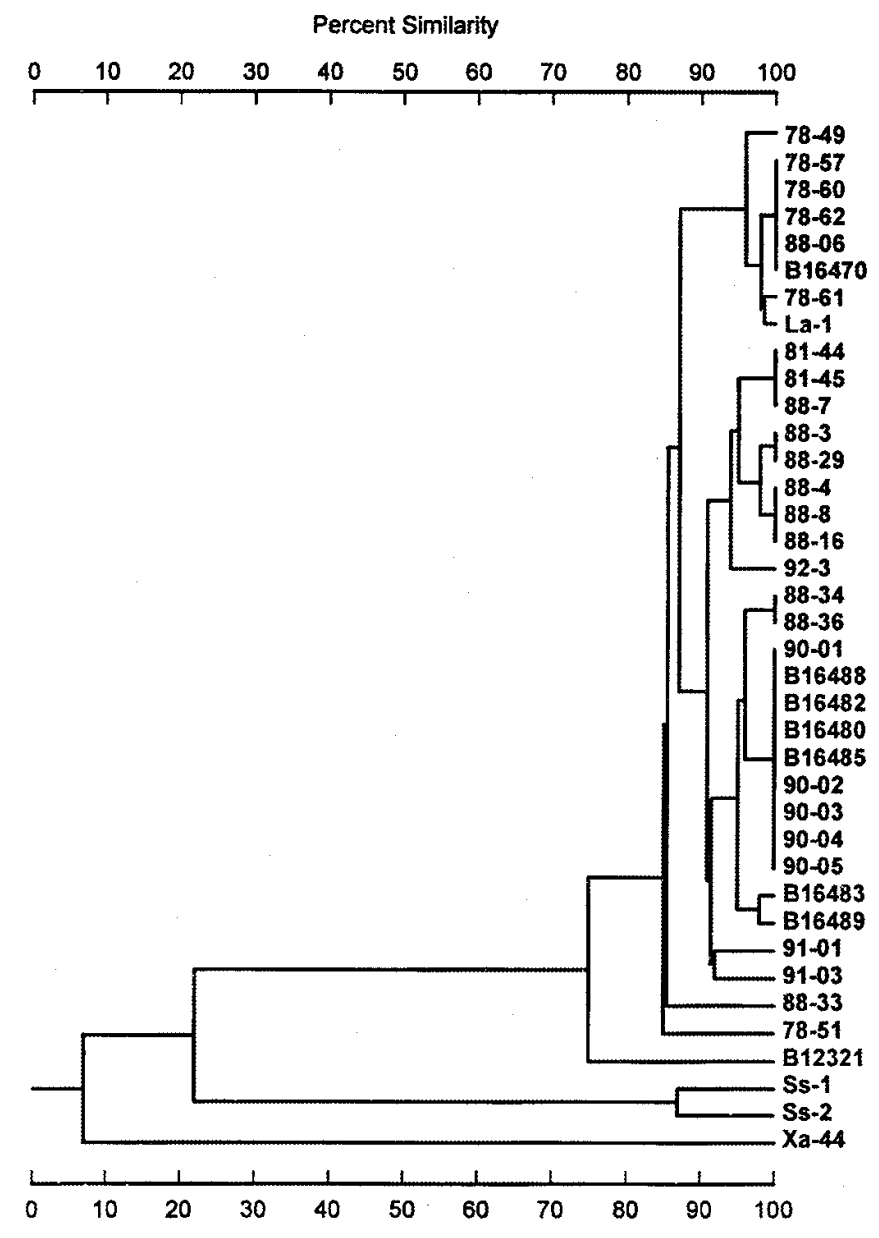

Fig. 4. Dendrogram showing similarity of 35 Streptomyces ipomoeae, 2 Streptomyces scabies, and 1 Xanthomonas albilineans strains based on the combination of BOX, enterobacterial repetitive intergenic consensus (ERIC), and repetitive extragenic palindromic (REP) polymerase chain reaction data using the unweighted pair group mathematical averaging method. of the two Streptomyces species. At $84 \%$ similarity, ERIC PCR discriminated three clusters with B12321 as a single-member cluster; 78-49, 78-57, 78-60, 78-62, La-1, 88-6, and B16470 as a second cluster; and all other $S$. ipomoeae strains grouped into another cluster. Of the 35 S. ipomoeae strains, 34 shared $\geq 78 \%$ similarity. All $S$ ipomoeae strains shared $\geq 66 \%$ similarity. The REP PCR results differed from those of BOX PCR and ERIC PCR. Of the 35 S. ipomoeae strains, 31 grouped into a cluster at $87 \%$ similarity with $88-33,88-34,88-36$, and B12321 outside the cluster. All the $S$. ipomoeae strains, except B12321, shared $\geq 80 \%$ similarity. All 35 S. ipomoeae strains grouped into a single cluster at $78 \%$ similarity. In the dendrogram based on the combination of all three sets of PCR data (Fig. 4), 32 of the S. ipomoeae strains grouped into one cluster at $87 \%$ similarity with $88-33,78-51$, and B12321 outside this cluster. Except for B12321, all other strains grouped into one cluster at $85 \%$ similarity. All S. ipomoeae strains shared $75 \%$ similarity.

The Ss-1 and Ss-2 S. scabies strains showed very low similarity with the $S$. ipomoeae strains, ranging from $15 \%$ for REP PCR to $27 \%$ for ERIC PCR. However, the similarities between Ss-1 and Ss-2 were 79, 87, 92, and 93\% for BOX, combined, REP, and ERIC PCR, respectively. The Gram-negative $X$. albilineans strain, Xa-44, invariably exhibited very low similarity with either the $S$. ipomoeae strains or S. scabies strains tested.

\section{DISCUSSION}

The methods used in this and previous studies $(1,22)$ indicate that $S$. ipomoeae is a species with a relatively high degree of genetic homogeneity. There was greater uniformity among strains of $S$. ipomoeae than has been observed within $S$. scabies $(7,13,46)$. Some strains even showed $100 \%$ similarity by rep-PCR. However, repPCR banding patterns may represent only a small proportion of the genome, and bands with the same electrophoretic mobility were not compared for DNA sequence homology. Partial 16S rDNA sequence analysis of four S. ipomoeae strains (78-49, B16483, 88-03, and the neotype strain B12321) showed them to share $100 \%$ sequence similarity in the region analyzed (data not shown). This finding supports the genetic homogeneity demonstrated in the current study. It is not clear whether S. ipomoeae strains showed such a high similarity with each other because they evolved only recently or because the strains are derived from the same clonal population. Since S. ipomoeae has been found only in association with infected sweetpotato (nonpathogenic strains have not been isolated from nature), it is possible that its geographic distribution may be determined by movement of the crop, which is clonally propagated. The known geographic distribution of S. ipomoeae is restricted to the United States and Japan but, since symptoms similar to those of Streptomyces soil rot have been observed in other countries, the distribution may be wider than currently recognized. Despite the observed genetic homogeneity, the strains in this study could be differentiated into three distinct groups based on inhibitory interactions, suggesting that there may be biologically significant variation within the species.

All strains that were $100 \%$ similar in either ERIC PCR, REP $\mathrm{PCR}$, or the combination of the three rep-PCR tests were also in the same inhibition group. However, strains with identical BOX PCR profiles included members of different inhibition groups. This is likely since BOX PCR may detect conserved regions of the $S$. ipomoeae genome, while the other two rep-PCR primer pairs generally amplify less-conserved regions $(28,48)$. Furthermore, $S$. ipomoeae and $S$. scabies were quite dissimilar in rep-PCR profiles, and even the BOX PCR profiles showed great differences. All 35 strains of $S$. ipomoeae tested produced five intense bands that were not produced by either of the two $S$. scabies strains tested. This also confirms earlier results (40) in which three strains of $S$. ipomoeae and two strains of $S$. acidiscabies formed clusters that were discrete from each other and from pathogenic and nonpatho- 
genic $S$. scabies, which support observations that these are distinct species $(1,13,22)$. The BOX PCR profiles shown by Sadowsky et al. (40) appear to be the same for strains $88-07$ and 88-29 but, as in this study, distinct from B12321.

The results of this study suggest that BOX PCR might provide a starting point for species-specific detection of $S$. ipomoeae by comparison of the BOX PCR fingerprints, by using a species-specific band as a hybridization probe, or by using sequence information from such a band to design species-specific primers. These approaches might be more specific if tests were based on pathogenicity-related genes. Although pathogenicity genes have not been identified for $S$. ipomoeae, it has been shown that necl was conserved among Streptomyces spp. that produce thaxtomin A and cause potato scab disease (3). ERIC PCR and REP PCR may provide supplementary methods for strain-specific tests within $S$. ipomoeae. REP PCR fingerprints and the construction of strainspecific DNA probes enabled detection of Burkholderia cepacia G4 at very low concentration (10 CFU of $B$. cepacia $\mathrm{G} 4$ in a mixture with $10^{5} \mathrm{CFU}$ of nontarget strains) (32). Other workers have failed to get consistent results with ERIC and REP PCR fingerprinting (40), suggesting that amplification reactions primed by REP and ERIC primers may not be as stable as those by the BOX primer. Combining the BOX, ERIC, and REP PCR results provided more information and, therefore, seems to offer a more reliable approach for assessing genetic diversity in S. ipomoeae strains.

The neotype strain of S. ipomoeae, B12321 (= ATCC-25462), has previously exhibited lower DNA relatedness (22) and different AseI digestion profiles in low-frequency restriction fragment analysis (1). In this study, it had different inhibition grouping and patterns of rep-PCR fingerprinting from other $S$. ipomoeae strains. Pathogenicity tests showed that this strain also has lost pathogenicity to sweetpotato. A recent study by King et al. (19) showed that strain ATCC-25462 has lost the ability to produce detectable levels of thaxtomin $\mathrm{C}$ when grown on potato tuber or sweetpotato storage root slices, while other $S$. ipomoeae strains produced significant quantities of this putative phytotoxin. The mechanism of loss of production of thaxtomin $\mathrm{C}$ and pathogenicity is still not clear; possibly, genes for production or regulation of thaxtomin $\mathrm{C}$ production had been deleted or been altered by transposable elements. The presumed genetic changes in B12321 may be related to prolonged subculturing on artificial media for many years (37) and instability of the Streptomyces genome (38). However, B12321 still has many characteristics consistent with the description of $S$. ipomoeae, including blue spores and other physiological characteristics. In spite of the differences between the neotype strain of $S$. ipomoeae and other virulent strains, the average of $85 \%$ DNA homology between B12321 and other S. ipomoeae strains tested (22) is still much higher than the proposed value of $\geq 70 \%$ DNA homology for a species (16). The relatively high similarity of B12321 with other S. ipomoeae strains in rep-PCR fingerprinting, ranging from 72 to $98 \%$ in the combined rep-PCR results, and the results of partial $16 \mathrm{~S}$ rDNA sequencing also tend to support the continued inclusion of B12321 in S. ipomoeae. However, considering the differences found in several studies between B12321 and all other strains, it is questionable whether it should be retained as the neotype strain of S. ipomoeae.

The mechanisms of inhibition among the strains of $S$. ipomoeae are unknown but are the subject of continuing investigation. The reactions reported here differ from those described previously for $S$. scabies (33), in that not all strains of $S$. ipomoeae induced an inhibition reaction and there was no apparent correlation with plasmid profiles. The broad inhibition zones we observed were similar in superficial appearance to those caused by bacteriocins in other bacterial genera (45), which suggests that an inhibitory substance diffused into the surrounding medium. Standard bacteriocin assays also were conducted in which the producing strain was grown, fumigated with chloroform vapors, and overlaid with SIGA seeded with the test strain. The group III strains induced inhibition zones similar to those observed in the assays reported here, but the group II strains did not induce inhibition (data not shown). Furthermore, group II and III strains of S. ipomoeae did not inhibit a variety of other bacteria (data not shown). Although bacteriocins have been studied extensively in some other bacterial genera, there is little information on their occurrence in Streptomyces (39).

Plasmids of various sizes have been previously observed in five S. ipomoeae strains (1). All five strains investigated in that study are members of inhibition group II. The results of the current study of 36 strains corroborated the previous results. Overall, there appeared to be no correlation between plasmid profile and inhibition group or pathogenicity. The 28 pathogenic strains and each inhibition group included both strains that harbored plasmids and strains in which plasmids were not detected. Although the distribution of plasmids throughout the three inhibition groups did not suggest any specific relationship between plasmid content and inhibition phenotype, further study of these plasmids should prove worthwhile. Characterization of the plasmids would, for example, allow the degree of relatedness between plasmids of apparently the same size in different strains to be determined and may suggest the origin of these extrachromosomal elements. Acquisition of the plasmids by lateral transfer from another Streptomyces strain, or other non-Streptomyces bacterium, is plausible, given the evidence of conjugal transfer of plasmids between $S$. ipomoeae strains suggested by the pocking phenotype.

Pocking was elicited by a number of challenge strains in our inhibition assays; however, some pock-producing strains did not appear to contain any plasmid species. In such strains, it is possible that autonomous plasmids are in fact present, but were not detectable under our experimental conditions. Pocking in Streptomyces has also been shown to be associated with the transfer of plasmids that are normally integrated in the chromosomes of nonmating cells, and upon mating, are excised and transferred into recipients (15). The relationship, if any, between such integrated plasmids and our results is currently being investigated.

Only one strain of $S$. ipomoeae, B12321, was not pathogenic on sweetpotato, and it was also the only strain tested that failed to produce thaxtomin C (19). Further research should be conducted to determine if thaxtomin $\mathrm{C}$ is a prerequisite or byproduct of pathogenesis of S. ipomoeae (19). B12321 may be useful in understanding the genetics of thaxtomin $\mathrm{C}$ production.

\section{ACKNOWLEDGMENTS}

Approved for publication by the director of the Louisiana Agricultural Experiment Station as manuscript 38-98-0154. We thank S. Lopes, J.-W. Hyun, M. Hoy, and K. E. Damann, Jr. for their advice and assistance.

\section{LITERATURE CITED}

1. Beyazova, M., and Lechevalier, M. P. 1993. Taxonomic utility of restriction endonuclease fingerprinting of large DNA fragments from Streptomyces strains. Int. J. Syst. Bacteriol. 43:674-682.

2. Bowers, J. H., Kinkel, L. L., and Jones, R. K. 1995. Classification of pathogenic strains of Streptomyces spp. using fatty acid analysis. (Abstr.) Phytopathology 85:1188.

3. Bukhalid, R. A., Chung, S., and Loria, R. 1997. The pathogenicity-related gene, nec 1 , is conserved among geographically and genetically diverse plant pathogenic Streptomyces species that produce thaxtomin A. (Abstr.) Phytopathology 87:S13.

4. Clark, C. A., and Lawrence, A. 1981. Morphology of spore-bearing structures in Streptomyces ipomoea. Can. J. Microbiol. 27:575-579.

5. Clark, C. A., and Moyer, J. W. 1988. Compendium of Sweet Potato Diseases. The American Phytopathological Society, St. Paul, MN.

6. Clark, C. A., Moyer, J. W., and Dukes, P. D. 1992. Diseases. Pages 88105 in: Fifty Years of Collaborative Sweetpotato Research, 1939-1989. A. Jones and J. C. Bouwkamp, eds. South. Coop. Ser. Bull. No. 369.

7. Doering-Saad, C., Kampfer, P., Manulis, S., Kritzman, G., Schneider, J., Zakrzewska-Czerwinska, J., Schrempf, H., and Barash, I. 1992. Diversity among Streptomyces strains causing potato scab. Appl. Environ. Microbiol. 58:3932-3940. 
8. Doi, K., Saeki, M. C., Ono, Y., and Ogata, S. 1995. Plasmid formation and its relation to the formation of spontaneously developing pocks in Streptomyces azureus ATCC 14921. J. Appl. Bacteriol. 79:237-243.

9. Faucher, E., Otrysko, B., Paradis, E., Hodge, N. C., Stall, R. E., and Beaulieu, C. 1993. Characterization of streptomycetes causing russet scab in Quebec. Plant Dis. 77:1217-1220.

10. Faucher, E., Paradis, E., Goyer, C., Hodge, N. C., Hogue, R., Stall, R. E., and Beaulieu, C. 1995. Characterization of Streptomycetes causing deeppitted scab of potato in Quebec, Canada. Int. J. Syst. Bacteriol. 45:222-225.

11. Faucher, E., Savard, T., and Beaulieu, C. 1992. Characterization of actinomycetes isolated from common scab lesions on potato tubers. Can. J. Plant Pathol. 14:197-202.

12. Goyer, C., Faucher, E., and Beaulieu, C. 1996. Streptomyces caviscabies sp. nov. from deep-pitted lesions in potatoes in Québec, Canada. Int. J. Syst. Bacteriol. 46:635-639.

13. Healy, F. G., and Lambert, D. H. 1991. Relationships among Streptomyces spp. causing potato scab. Int. J. Syst. Bacteriol. 41:479-482.

14. Hopwood, D. A., Bibb, M. J., Chater, K. F., Kieser, T., Bruton, C. J., Kieser, H. M., Lydiate, D. J., Smith, C. P., Ward, J. M., and Schrempf, H. 1985. Genetic Manipulation of Streptomyces, A Laboratory Manual. The John Innes Foundation, Norwich, United Kingdom.

15. Hopwood, D. A., and Kieser, T. 1993. Conjugative plasmids of Streptomyces. Pages 293-311 in: Bacterial Conjugation. D. B. Clewell, ed. Plenum Press, New York.

16. Johnson, J. 1989. Nucleic acids in bacterial classification. Pages 2306-2309 in: Bergey's Manual of Systemic Bacteriology, Vol. 4. S. T. Williams, M. E. Sharpe, and J. G. Holt, eds. Williams \& Wilkins, Baltimore, MD.

17. Kämpfer, P., and Kroppenstedt, R. M. 1991. Probabilistic identification of streptomycetes using miniaturized physiological tests. J. Gen. Microbiol. 137:1893-1902.

18. Kieser, H., Kieser, T., and Hopwood, D. A. 1992. A combined genetic and physical map of the Streptomyces coelicolor A3(2) chromosome. J. Bacteriol. 174:5496-5507.

19. King, R. R., Lawrence, C. H., Calhoun, L. A., and Ristaino, J. B. 1994. Isolation and characterization of thaxtomin-type phytotoxins associated with Streptomyces ipomoeae. J. Agric. Food Chem. 42:1791-1794.

20. Kurylowicz, W., Paszkiewicz, A., Woznicka, W., and Kurzatowski, W. 1976. Numerical taxonomy of streptomycetes (ISP strains). Pages 323-340 in: Actinomycetes: The Boundary Organisms. T. Arai, ed. Toppan Co., Tokyo.

21. Küster, E. 1972. Simple working key for the classification and identification of named taxa included in the International Streptomyces Project. Int. J. Syst. Bacteriol. 22:139-148.

22. Labeda, D. P., and Lyons, A. J. 1992. DNA relatedness among strains of the sweet potato pathogen Streptomyces ipomoea (Person and Martin 1940) Waksman and Henrici 1948. Appl. Environ. Microbiol. 58:532-535.

23. Lambert, D. H., and Loria, R. 1989. Streptomyces scabies sp. nov., nom. rev. Int. J. Syst. Bacteriol. 39:387-392.

24. Lambert, D. H., and Loria, R. 1989. Streptomyces acidiscabies sp. nov. Int. J. Syst. Bacteriol. 39:393-396.

25. Locci, R. 1994. Actinomycetes as plant pathogens. Eur. J. Plant Pathol. 100:179-200.

26. Lopes, S. A. 1996. Xanthomonas albilineans, Identification and Infectivity Titration in Sugarcane. Ph.D. dissertation. Louisiana State University, Baton Rouge.

27. Loria, R., Bukhalid, R. A., Fry, B. A., and King, R. R. 1997. Plant pathogenicity in the genus Streptomyces. Plant Dis. 81:836-846.

28. Louws, F. J., Fulbright, D. W., Stephens, C. T., and de Bruijin, F. J. 1992. Specific genomic fingerprinting of phytopathogenic Xanthomonas and Pseudomonas pathovars and strains generated with repetitive sequences and PCR. Appl. Environ. Microbiol. 60:2286-2295.

29. Louws, F. J., Fulbright, D. W., Stephens, C. T., and de Bruijin, F. J. 1995. Differentiation of genomic structure by rep-PCR fingerprinting to rap- idly classify Xanthomonas campestris pv. vesicatoria. Phytopathology $85: 528-536$

30. Lupski, J. R., and Weinstock, G. M. 1992. Short, interspersed repetitive DNA sequences in prokaryotic genomes. J. Bacteriol. 174:4525-4529.

31. Martin, W. J., Hernandez, T. P., and Hernandez, T. P. 1975. Development and disease reaction of Jasper, a new soil rot-resistant sweet potato variety from Louisiana. Plant Dis. Rep. 59:388-391.

32. Matheson, V. G., Munakata-Marr, J., Hopkins, G. D., McCarthy, P. L., Tiedie, J. M., and Forney, L. J. 1997. A novel means to develop strainspecific DNA probes for detecting bacteria in the environment. Appl. Environ. Microbiol. 63:2863-2869.

33. McQueen, D. A. R., Anderson, N. A., and Schottel, J. L. 1985. Inhibitory reactions between natural isolates of Streptomyces. J. Gen. Microbiol. 131:1149-1155.

34. Moyer, J. W., Campbell, C. L., Echandi, E., and Collins, W. W. 1984. Improved methodology for evaluating resistance in sweet potato to Streptomyces ipomoea. Phytopathology 74:494-497.

35. Paradis, E., Goyer, C., Hodge, N. C., Hogue, R., Stall, R. E., and Beaulieu, C. 1994. Fatty acid and protein profiles of Streptomyces scabies strains isolated in eastern Canada. Int. J. Syst. Bacteriol. 44:561-564.

36. Perkins, D. D. 1962. Preservation of Neurospora stock cultures with anhydrous silica gel. Can. J. Microbiol. 8:591-594.

37. Person, L. H., and Martin, W. J. 1940. Soil rot of sweet potatoes in Louisiana. Phytopathology 30:913-926.

38. Piret, J. M., and Demain, A. L. 1988. Actinomycetes in biotechnology: An overview. Pages 462-482 in: Actinomycetes in Biotechnology. M. Goodfellow, S. T. Williams, and M. Mordarski, eds. Academic Press, San Diego, CA.

39. Roelants, P., and Naudts, F. 1964. Properties of a bacteriocin-like substance produced by Streptomyces virginiae. Antonie Leeuwenhoek 30: 45-53.

40. Sadowsky, M. J., Kinkel, L. L., Bowers, J. H., and Schottel, J. L. 1996. Use of repetitive intergenic DNA sequences to classify pathogenic and diseasesuppressive Streptomyces strains. Appl. Environ. Microbiol. 62:3489-3493.

41. Shirling, R. B., and Gottlieb, D. 1966. Methods for characterization of Streptomyces species. Int. J. Syst. Bacteriol. 16:313-340.

42. Shirling, R. B., and Gottlieb, D. 1969. Cooperative description of type cultures of Streptomyces. IV. Species descriptions from the second, third and fourth studies. Int. J. Syst. Bacteriol. 19:391-512.

43. Simonet, P., Normand, P., Moiroud, A., and Lalonde, M. 1985. Restriction enzyme digestions patterns of Frankia plasmids. Plant Soil 87:49-60.

44. Spooner, F., Medina, C., and Fulbright, D. 1995. Fingerprinting genomes of potato scab-causing Streptomyces species with repetitive extragenic sequences and the polymerase chain reaction technique. (Abstr.) Phytopathology 85:1162.

45. Tagg, J. R. 1992. Bacteriocins of Gram-positive bacteria: An opinion regarding their nature, nomenclature and numbers. Pages 33-34 in: Bacteriocins, Microcins, and Lantibiotics. R. James, C. Lazdunski, and F. Pattus, eds. NATO ASI series H, 65. Springer, Berlin.

46. Takeuchi, T., Sawada, H., Tanaka, F., and Matsuda, I. 1996. Phylogenetic analysis of Streptomyces spp. causing potato scab based on $16 \mathrm{~S}$ rRNA sequences. Int. J. Syst. Bacteriol. 46:476-479.

47. Tashiro, N., Miyashita, K., and Suzui, T. 1990. Taxonomic studies on the Streptomyces species, isolated as causal organisms of potato common scab. Ann. Phytopathol. Soc. Jpn. 56:73-82.

48. Versalovic, J., Schneither, M., De Bruijin, F. J., and Lupski, J. R. 1994. Genomic fingerprinting of bacteria using repetitive sequence-based polymerase chain reaction. Methods Mol. Cell. Biol. 5:25-40.

49. Williams, S. T., Goodfellow, M., and Alderson, G. 1989. Genus Streptomyces Waksman and Henrici 1943, 339. Pages 2452-2492 in: Bergey's Manual of Systematic Bacteriology, Vol. 4. S. T. Williams, M. E. Sharpe, and J. G. Holt, eds. Williams \& Wilkins, Baltimore. 